\title{
Influence of Improving Materials of Forest Roads on the Surrounding Environment
}

\author{
Lenka Ševelová*, Pablo Fernández Arias, Miloslav Šlezingr \\ Faculty of Forestry and Wood Technology, Mendel University in Brno, Brno, Czech Republic
}

Received: 24 September 2019

Accepted: 12 December 2019

\begin{abstract}
Ensuring the efficiency of forest management and the availability of landscape areas requires a quality transport network. However, any structure and its subsequent use generally contributes to a certain disruption of surrounding ecosystems, soil degradation, erosion and changes in vegetation. The presented study analyzes the effects and impacts of the five types of improving materials used to improve the load-bearing capacity of low-volume roads. Two basic types of analyses were performed: the classification of mechanical properties of soil for determining fine clay particle proportions and the chemical testing for $\mathrm{pH}$ and carbonate determination. The samples were always collected at three distances from the roadside, at two height levels and in two years: 2012 and 2017. The aim of the study was to quantify the effects of improving materials on the $\mathrm{pH}$ changes as well as the carbonate levels, and to compare their changes over the course of five years. Also, we have highlighted the possibilities of "biological tools" (vegetation) to control and minimize the impact of human activities. Vegetative control, or phytoremediation, increases soil resistance to erosion, improves water retention in a landscape and maintains the original balance. It seems to be an effective tool for reduction of the impact of pavement construction materials and technologies on the surrounding environment.
\end{abstract}

Keywords: low-volume road, soil improvement, erosion, forest runoff, phytoremediation

\section{Introduction}

Low-volume roads (LVRs) mainly provide access to landscape areas for economic and recreational reasons, as well as to ensure accessibility outside public transport networks as part of an integrated rescue system. LVRs are defined by the American Association of State Highway and Transportation Officials (AASTHO) for loads determined by the average daily intensity of less than 400 heavy trucks for all traffic lanes in the design period [1]. Pavement construction of these roads uses

*e-mail: lenka.sevelova@mendelu.cz mainly natural materials such as natural aggregates of various fractions, lime, etc., but also recycled materials. Each of the used materials, including the natural ones, is foreign to the given location. Due to climatic and erosive processes it washes out into the surrounding environment, where it can initiate the process of changes in the natural chemical composition of the soil and thus also changes in surrounding vegetation. This negative impact on the surrounding environment is very important, especially in the case of forest roads.

Erosion is a natural part of the geological cycle, which causes the changes that a relief undergoes due to the action of different agents. The processes that support erosion can be wind, water currents, temperature 
changes and the action of living creatures. The different erosive processes, either natural or caused by human activity, cause different materials to be moved and deposited in other areas where they did not exist before [2]. Human activities accelerate the process of erosion [3] and export of sediments through which they convert the soil into a non-renewable resource.

The movement of heavy machinery, both during pavement construction and its use, causes the compaction of the first centimeters of the soil, and thus hydrological function is modified [4]. Increased soil compaction decreases the root system's growth ability, which can be responsible for reducing the root growth of plants [5]. And thus it contributes to the change process of the surrounding ecosystem, too [6].

During forest road construction, measures must be adopted to minimize negative impacts on the environment. Forest road construction must be carried out in the dry season, inert materials must be used and maximum compaction of the construction layers must be ensured [7]. But all the materials used for pavement structures as well as for subgrade improvement could have an impact on the environment in case they wash out to the surrounding landscape where a change in natural chemical composition of the soil may occur.

Vegetative control, or phytoremediation, is defined as the use of plants to remediate, treat, stabilize, or control contaminated soils. Phytoremediation exploits the natural plant physiological processes [8] by absorption of some of the contaminants and by the natural stabilization function of the root system. Introduced in the "biotechnology of slopes", this technique provides the stabilization of slopes using vegetation and additional structural elements for erosion control [9]. An example of natural revegetation on forest road slopes can be found in [10], where the possibility to protect the slopes from erosive processes by means of planting bushes or sowing of grass was introduced.

The aim of our study is to quantify the chemical changes ( $\mathrm{pH}$ value) in the forest road surroundings caused by the leaching of materials used to improve the subsoil-bearing capacity as a result of erosive processes (both natural and human) during construction, as well as during road use. On the basis of this quantification, we can verify the assumption that a significant impact on the surrounding ecosystem can be expected only in the close vicinity of the road.

\section{Material and Methods}

\section{Study Area}

The low-volume forest road that is being analyzed is located in the Czech Republic, near the city of Brno (the location of the monitored area is shown in Fig. 1, as created using QGIS software [11]). The road was built as an experimental construction in 2012 as a result of project TA01020326, "Optimization of design and realization of low-volume roads", granted by the Technology Agency of the Czech Republic. It was designed to test standard as well as innovative materials that are able to improve the load-bearing capacity of subgrade. Besides monitoring the impact on the loadbearing capacity, the impact of these materials on the roadside surrounding the environment was monitored too.

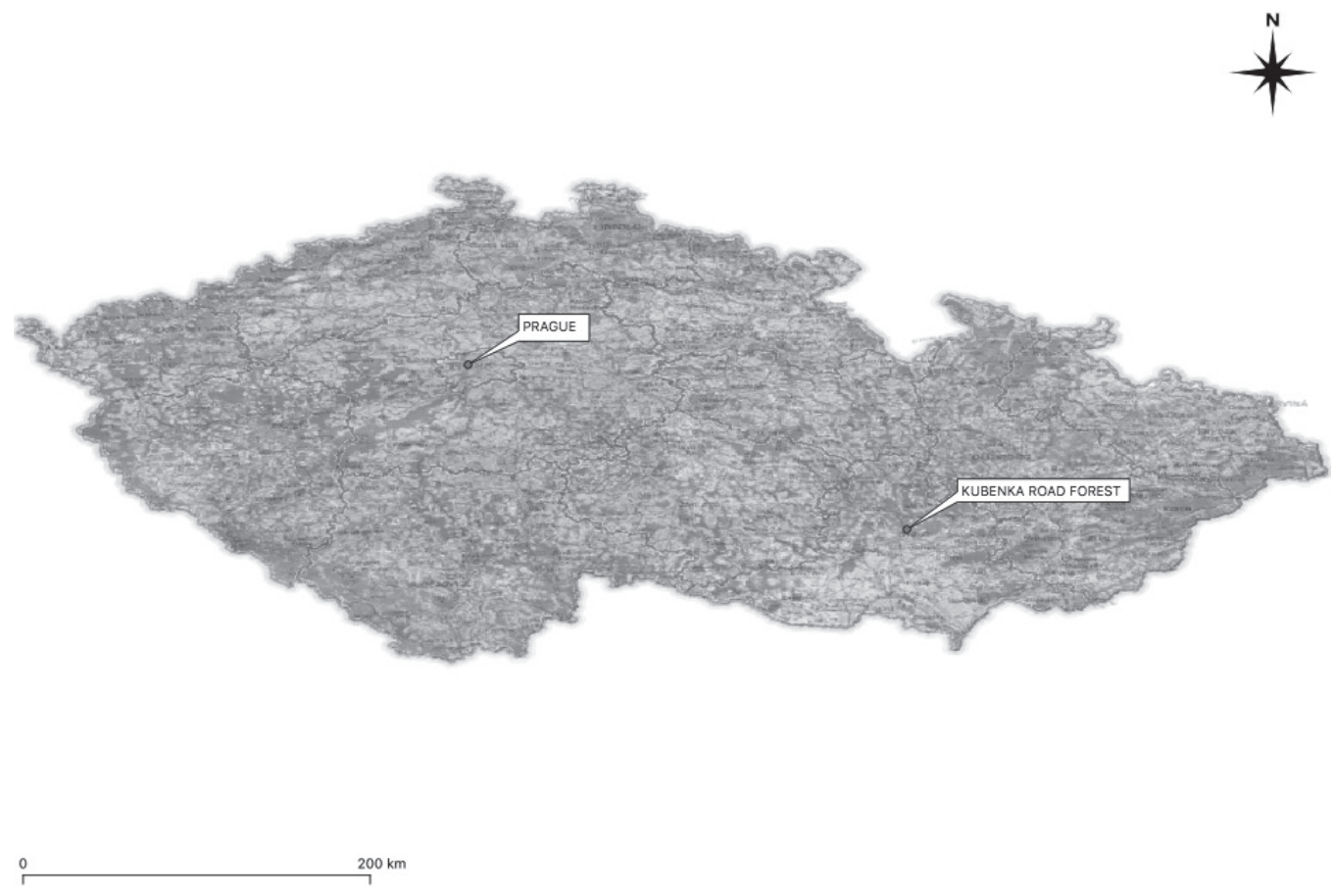

Fig. 1. Position of the analyzed low-volume road (Kubenka) in QGIS (V 3.4). 
The experimental road has a length of 309 meters with a slope of $3 \%$ (Fig. 1). The beginning of the road is located $388 \mathrm{~m}$ above sea level and the end is at $372 \mathrm{~m}$. The climate in the monitored area is classified as warm and temperate [12] and is classified as Cfb by the Köppen-Geiger system. The average temperature is $9.0^{\circ} \mathrm{C}$. Temperatures are highest in July, at around $18.6^{\circ} \mathrm{C}$. At $-2.2^{\circ} \mathrm{C}$ on average, January is the coldest month of the year. Rainfall is significant, with precipitation even during the driest month. The average precipitation is $518 \mathrm{~mm}$. The lowest amount of rain occurs in February, with an average of $23 \mathrm{~mm}$. In June, the precipitation reaches its peak with an average of $75 \mathrm{~mm}$.

In the southeastern part of Brno there are mostly tertiary sedimentary rocks (clays, sands) and the subsoil consists of original igneous rocks, such as granite and volcanic rocks. The monitored area where the experimental road was built consists of rocks of various origins and age in the subsoil. There are also several layers of original clay and sand, which cover the older rocks.

The vegetation in the monitored area is a typical European mixed forest that consists mainly of Picea abies, Larix decidua, Tilia cordata, Castanea sativa, Ulmus minor, Quercus robur and Pinus sylvestris. Among the most widespread herbaceous plants are Poa nemoralis $35 \%$, Poa angustifolia $10 \%$, Dactylis poligama $20 \%$, Brachypodium sylvaticum $5 \%$, Myosotis sylvatica $5 \%$, Veronica chamaedrys 5\%, Campanula persicifolia $3 \%$, Ajuga reptans 2\%, Vincetoxicum hirundinaria 3\%, Pyrethrum corymbosum 5\%, Clinopodium vulgare $6 \%$ and Hypericum perforatum $1 \%$.

The experimental road consists of two sections, each $147 \mathrm{~m}$ long, with a gradual transition part among them [13]. The pavement of the first section consists of one construction layer only, whereas the second section pavement consists of two construction layers. For the pavement construction only natural crushed gravel of different fractions sourced from the nearby quarry was used in both sections. Each road section is divided into seven segments. In each segment different materials of subgrade improvement were tested (Fig. 2).

The first (Segment X1) and the second segment (X2) were improved by fluid fly ash of different origin: ash I and ash II. The third segment (X3) was improved by lime, the fourth (X4) by the commercial product Dorosol (mixture of $1 / 2$ lime $+1 / 2$ cement ), the fifth (X5) by hemp fibre, the sixth (X6) by fine aggregates $0.4 \mathrm{~mm}$ and the last one (X7) by a recycled building brick material [14]. In the presented study only the five segments (X1-X5) in the first section were analyzed.

\section{Selecting Samples}

The material samples to be analyzed were taken at the midpoint of each of the five segments, in three profiles that were determined at the same distance from the longitudinal axis of the road and at two different heights (Fig. 1). They were collected on the right side of the roadside, where the runoff of the forest road is directed. The first profile sample (Y1) was collected from the drainage site, the second profile sample (Y2) $1 \mathrm{~m}$ from the drainage site and the third profile sample (Y3) $2 \mathrm{~m}$ from the drainage site (Fig. 2). Two different depth levels for sample collection were determined: terrain surface (Z1) and a depth of $30 \mathrm{~cm}$ (Z2). As result, six samples of the possibly contaminated samples of soil were collected for each segment X1-X5. Each sample is marked by the code $\mathrm{X} / \mathrm{Y} / \mathrm{Z}$; where $\mathrm{X}$ is the segment number, $\mathrm{Y}$ is the distance from the longitudinal axis, and $\mathrm{Z}$ is the depth of the sample collection. Six samples were collected from each segment in 2012 as well as in 2017. A total of 60 samples from expected contaminated areas were collected.

In addition, blank tests of samples were performed. Blank tests were performed on samples collected from such a distance and a position from the segments that guarantee they were not affected by improvement materials. Marking these samples follows the same system as the samples collected from the roadside. The code of the blank sample is $\mathrm{Y} / \mathrm{Z}$, where $\mathrm{Y}$ is the collection position and $\mathrm{Z}$ is the depth of the specimen.

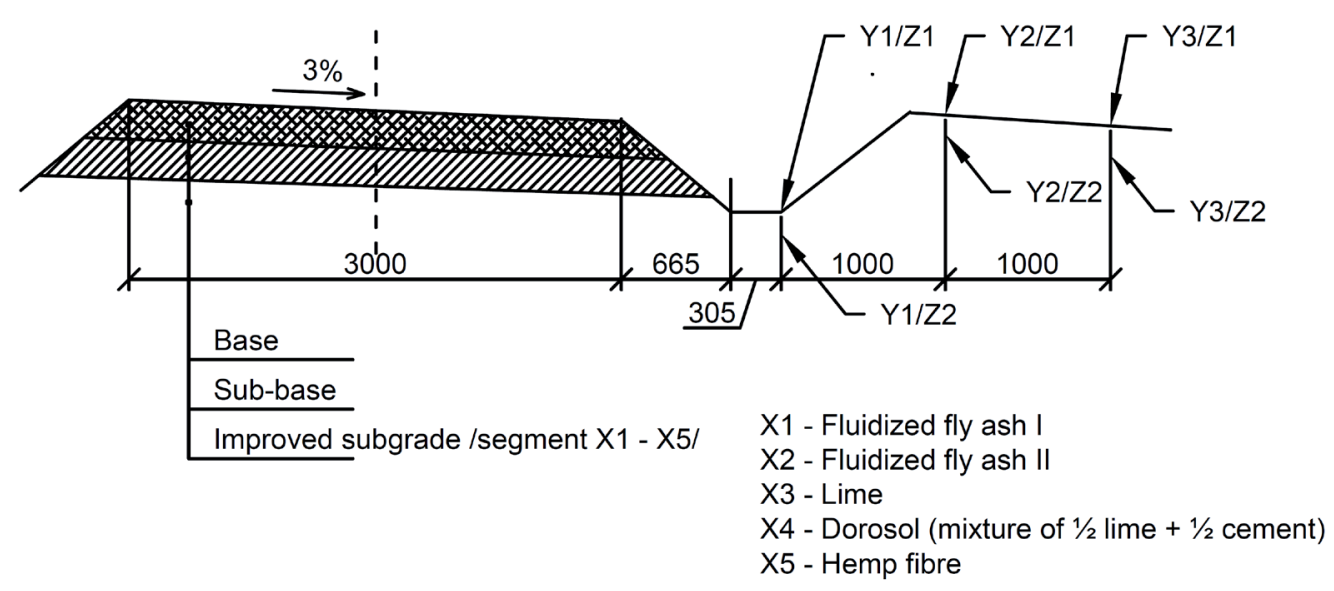

Fig. 2. Sample cross-section of segment X. 


\section{Geotechnical, Chemical and Statistical Analyses}

The geotechnical analyses consist of: a humidity test according to the protocol ČSN ISO/TS 17892-1 [15], sieving and aerometry test according to the protocol ČSN ISO/TS 17892-4 [16] and consistency (plasticliquid limit) or Atterberg boundary test according to the protocol ČSN ISO/TS 17892-12 [17]. All the tests were carried out in the laboratory of the Department of Landscape Management, Faculty of Forestry and Wood Technology, Mendel University in Brno. The above tests serve for the basic soil classification according to their granulometric composition and Atterberg plastic-liquid limits for the classification of soils according to Unified Soil Classification System (USCS) ČSN EN ISO 14689-1 [18] and ČSN EN ISO 14688-2 [19].

Two chemical analyses were carried out: analysis of $\mathrm{pH}$ according to the protocol ISO 10390:1994 [20], and analysis of total carbonates $\left(\mathrm{CO}_{3}\right)^{2-}$ according to the protocol ISO 10693:2015 [21]. All the tests were carried out at the Laboratory of the Department of Geology and Pedology, Faculty of Forestry and Wood Technology, Mendel University in Brno. The chemical test of $\mathrm{pH}$ determines alkalinity or acidity of a soil, the second one the percentage of total carbonate. The total amount of carbonates $\left(\mathrm{CO}_{3}\right)^{2-}$ was determined from the volume ratio of the amount of $\mathrm{CO}_{2}$ produced in the gaseous state as a function of Equation (1):

$$
\mathrm{CaCO}_{3}+\mathrm{HCl} \rightarrow \mathrm{CO}_{2}+\mathrm{CaCl}_{2}+\mathrm{H}_{2} \mathrm{O}
$$

Each collected sample was tested five times by the appropriate chemical test to minimize random error that may occur in any measurement. The data obtained from both chemical tests were statistically evaluated and basic statistical parameters were determined: minimal and maximal value, mean value, standard deviation, and coefficient of variation.

The initial assumption is that a significant impact on the surrounding ecosystem as a result of the leaching of materials used to improve the subsoil-bearing capacity can only be expected in the close vicinity of the road. To verify this assumption, statistical analysis was performed to determine the probability $\mathrm{p}_{\mathrm{f}}$ that the $\mathrm{pH}$ value in the non-affected area (blank test) comes from the basic set of $\mathrm{pH}$ values determined by the evaluation of samples taken in the areas affected by leaching. If this probability is very low, it can be stated that the $\mathrm{pH}$ value in the non-affected area with high probability does not come from the relevant basic set of affected $\mathrm{pH}$ values.

\section{Results and Discussion}

\section{Geotechnical Results}

Geotechnical test were carried out on samples of all five segments. Once the geotechnical tests were finished, the different types of soils were classified according to the regulation USCS. Table 1 shows the proportional amount of fine (F) fractions (smaller than $0,063 \mathrm{~mm}$ from the aerometric test) that is key for the classification, as well as the permeability rate. In Table 1 the identification of the results refers to the introduced code $\mathrm{X} / \mathrm{Y} / \mathrm{Z}$, where $\mathrm{X} 1-\mathrm{X} 5$ is the segment

Table 1. Classification of soils and Results of $\mathrm{pH}$ and $\mathrm{CaCO}_{3}$ analysis from 2012 and 2017.

\begin{tabular}{|c|c|c|c|c|c|c|c|c|c|c|c|}
\hline \multirow{3}{*}{ Segment } & \multirow{3}{*}{ Profile } & \multirow{3}{*}{ Soil } & \multirow{3}{*}{$\begin{array}{l}\text { Fraction } \\
\text { fine }(\%)\end{array}$} & \multicolumn{4}{|c|}{2012} & \multicolumn{4}{|c|}{2017} \\
\hline & & & & \multicolumn{2}{|c|}{$\mathrm{Z} 1$} & \multicolumn{2}{|c|}{$\mathrm{Z} 2$} & \multicolumn{2}{|c|}{$\mathrm{Z1}$} & \multicolumn{2}{|c|}{$\mathrm{Z} 2$} \\
\hline & & & & $\mathrm{pH}$ & $\left(\mathrm{CO}_{3}\right)^{2-}$ & $\mathrm{pH}$ & $\left(\mathrm{CO}_{3}\right)^{2-}$ & $\mathrm{pH}$ & $\left(\mathrm{CO}_{3}\right)^{2-}$ & $\mathrm{pH}$ & $\left(\mathrm{CO}_{3}\right)^{2-}$ \\
\hline \multirow{3}{*}{$\mathrm{X} 1$} & Y1 & S4-SM & 29.88 & 5.210 & 0.000 & 5.600 & 0.000 & 7.912 & 2.620 & 7.729 & 1.670 \\
\hline & Y2 & F3-MS & 37.43 & 6.170 & 0.040 & 6.050 & 0.000 & 8.056 & 2.020 & 7.690 & 0.614 \\
\hline & Y3 & F6-CL & 66.94 & 4.750 & 0.000 & 5.020 & 0.000 & 7.848 & 2.100 & 7.970 & 2.080 \\
\hline \multirow{3}{*}{$\mathrm{X} 2$} & Y1 & F4-CS & 55.24 & 7.260 & 0.110 & 6.120 & 0.000 & 7.804 & 1.672 & 7.920 & 7.640 \\
\hline & Y2 & \multirow{11}{*}{ F4-CS } & \multirow{11}{*}{$\begin{array}{c}\text { From } \\
40.00 \\
\text { to } 59.90\end{array}$} & 7.320 & 0.050 & 6.880 & 0.000 & 7.806 & 3.520 & 7.138 & 1.150 \\
\hline & Y3 & & & 6.980 & 0.000 & 6.690 & 0.000 & 7.626 & 1.000 & 7.226 & 0.860 \\
\hline \multirow{3}{*}{$\mathrm{X} 3$} & Y1 & & & 5.240 & 0.000 & 5.220 & 0.000 & 7.890 & 0.828 & 7.480 & 0.960 \\
\hline & Y2 & & & 4.870 & 0.000 & 4.890 & 0.000 & 7.936 & 1.960 & 7.674 & 0.200 \\
\hline & Y3 & & & 5.450 & 0.030 & 5.070 & 0.000 & 8.092 & 1.200 & 6.774 & 0.184 \\
\hline \multirow{3}{*}{$\mathrm{X} 4$} & Y1 & & & 6.030 & 0.000 & 5.900 & 0.000 & 7.854 & 0.564 & 7.578 & 0.304 \\
\hline & Y2 & & & 6.170 & 0.000 & 5.120 & 0.000 & 7.814 & 0.580 & 4.732 & 0.030 \\
\hline & Y3 & & & 5.440 & 0.030 & 5.160 & 0.000 & 7.614 & 0.210 & 4.644 & 0.010 \\
\hline \multirow{3}{*}{$\mathrm{X} 5$} & Y1 & & & 6.030 & 0.000 & 5.900 & 0.000 & 7.620 & 1.260 & 4.848 & 0.052 \\
\hline & Y2 & & & 6.170 & 0.000 & 5.120 & 0.000 & 7.044 & 0.210 & 4.484 & 0.038 \\
\hline & Y3 & & & 5.440 & 0.030 & 5.160 & 0.000 & 4.668 & 0.000 & 4.888 & 0.016 \\
\hline
\end{tabular}




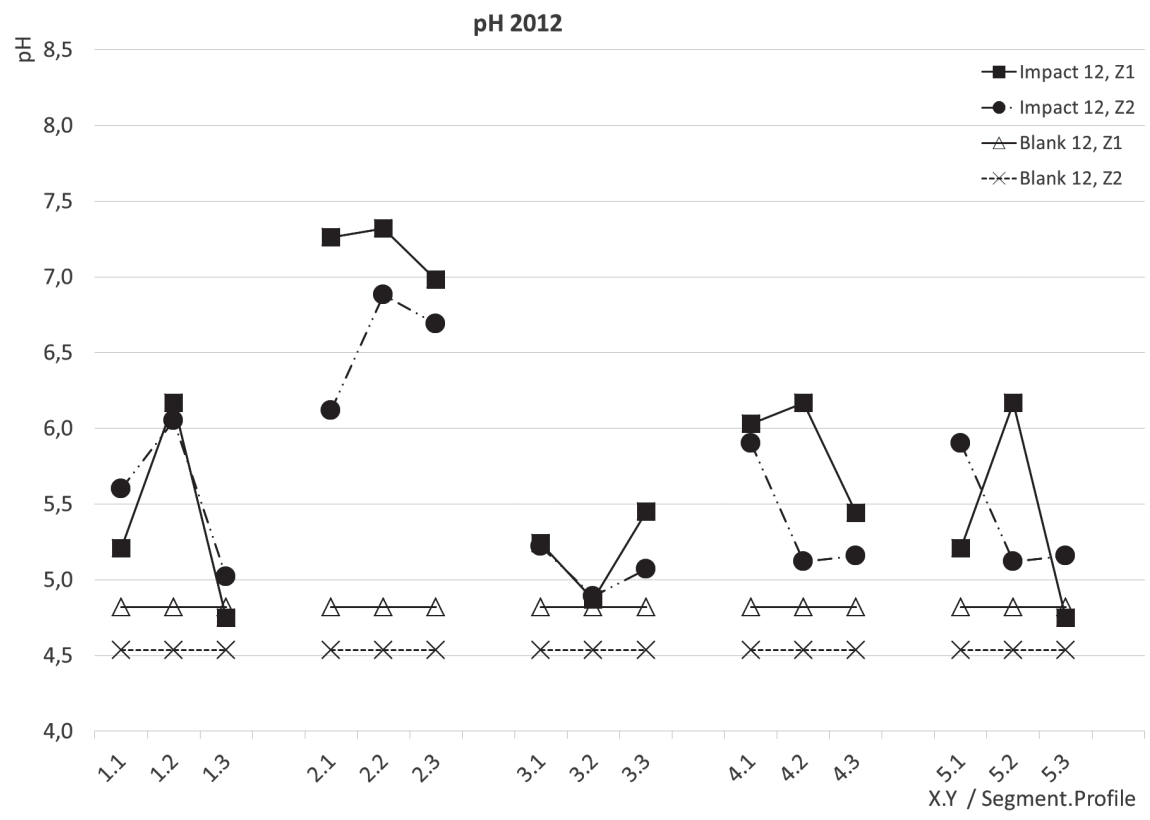

Fig. 3. Results of $\mathrm{pH}$ analysis from 2012.

number and Y1-Y3 is the distance from the longitudinal axis. Depth positions $\mathrm{Z} 1$ and $\mathrm{Z} 2$ are not considered in the geotechnical test as the sample was collected from the whole profile (Fig. 2).

Soil classification determines four different types of subgrade soil in the experimental road surroundings. Along segments X2-X5, the F4-CS soil is located in all three measured profiles. Only in segment $\mathrm{X} 1$ are there three different types of soils for the each profile Y1-Y3: for Y1 soil S4-SM, for Y2 soil F3-MS, and for Y3 soil F6-CL. Soil F4 defines sandy silt, including sandy clays with plastic index and fine sandy silt with a particle size smaller than $0.02 \mathrm{~mm}$. Soil CS defines clay and sand smaller than $0.02 \mathrm{~mm}$. Soil S4-SM silty sand, soil F3-MS is sandy silt and F6-CL is clay with low plasticity.

\section{Chemical Results}

The aim of the chemical analysis was to determine the impact of five materials used for improved pavement subgrade - fluid fly ash (ash I and ash II), lime, Dorosol, and hemp fibre - on the surrounding environment, and to compare changes that occurred in the course of 5 years. The first set of soil samples was collected in 2012 immediately after finishing the pavement construction, and in year 2017, after the road had been used for a period of five years. The obtained results illustrate how different improving materials can differently affect soil chemistry, i.e., $\mathrm{pH}$ value and carbonate content.

$\mathrm{pH}$ value is a dimensionless quantity of the acidity or alkalinity in the range 0 to 14 . In the following text, $\mathrm{pH}$ value is considered acidic in the range of $0-5.5$, neutral in the range of 5.5-8 and alkaline in the range of 8-14.
For the assessment of carbonate quantity $\left(\mathrm{CO}_{3}\right)^{2-}$, the following word expression will be used: carbonate content between 0.30 and $0.5 \%$ (very low), between 0.6 and 3\% (low), between 3.1 and 5\% (medium), between 5.1 and $10 \%$ (medium high), between 10.1 and $20 \%$ (high), between 20.1 and 40\% (very high) and more than $40.1 \%$ (extremely high).

From the analyses, four sets of $\mathrm{pH}$ value and carbonate content were obtained: two blank samples from areas not affected by the improvement in 2012 (Blank 12) and 2017 (Blank 17), and two samples affected by the improvement materials from 2012 (Impact 12) and from 2017 (Impact 17) (Table 1).

Mean values of $\mathrm{pH}$ from Blank 12 ranged from 4.5 to 4.8 (Fig. 3). Mean values of carbonate content ranged from 0.01 to $0.1 \%$ (Fig. 4). They were independent of depth.

The mean values of $\mathrm{pH}$ from Impact 12 ranged from 4.7 to 7.3 for surface sample collection (Z1) and from 4.8 to 6.9 for in-depth sample collection (Z2) (Fig. 3). The carbonate values were negligible and close to zero (Fig. 4).

Mean values of $\mathrm{pH}$ from samples Blank 17 ranged from 4.6 to 5.1 (Fig. 5). Carbonate values were negligible and close to zero (Fig. 6).

The mean values of $\mathrm{pH}$ from Impact 17 ranged from 4.6 to 8.1 for surface sample collection (Z1) and from 4.4 to 8.0 for in-depth sample collection (Z2) (Fig. 5). The carbonate values ranged from 0.0 to $3.5 \%$ for surface sample collection (Z1) and from 0.01 to $8.0 \%$ for in-depth sample collection (Z2) (Fig. 6).

All presented test results showed minimal deviations from the mean values. The standard deviation and coefficient of variation are very low.

By comparing the $\mathrm{pH}$ and carbonate values, only insignificant differences can be observed on samples 


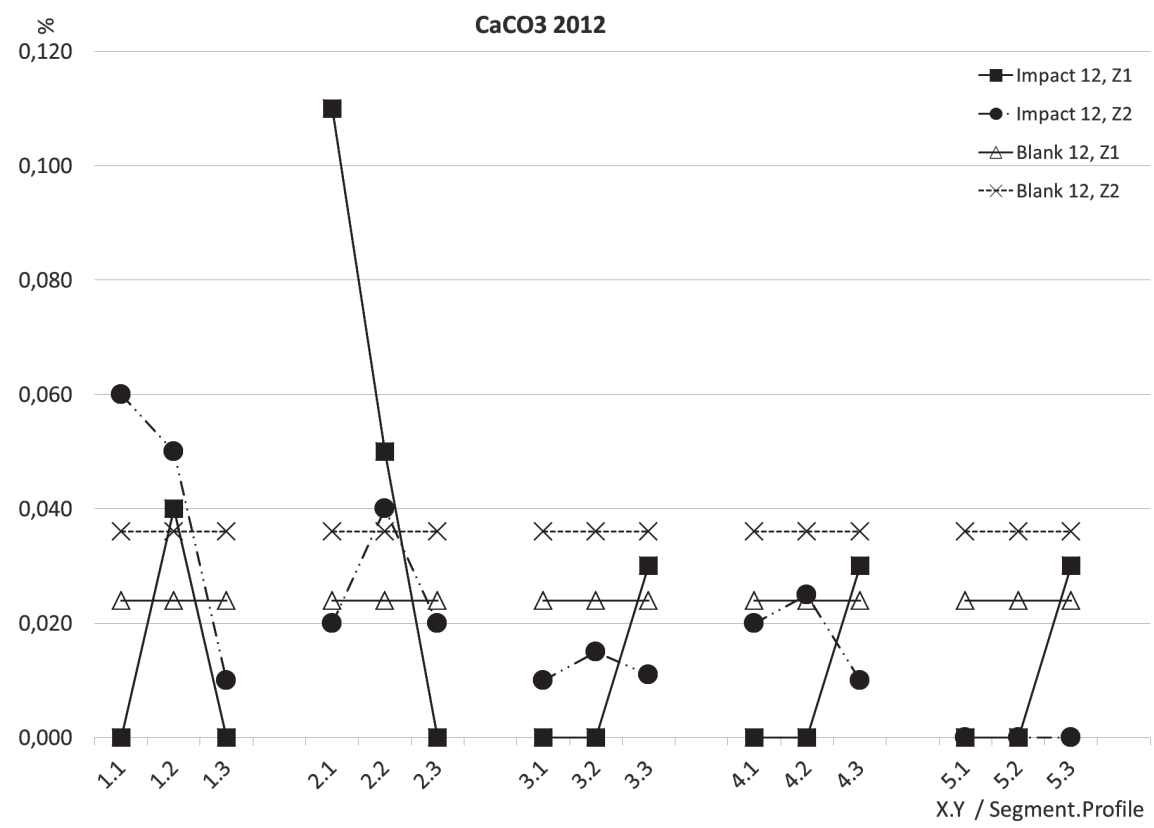

Fig. 4. Results of $\mathrm{CaCO}_{3}$ analysis from 2012.

taken from non-affected areas in 2012 and 2017 (Blank 12 and Blank 17) over five years. By 2017, the $\mathrm{pH}$ increased by $5.8 \%$ at the surface and by $3 . \%$ at depth. The $\mathrm{pH}$ remained acidic even after 5 years in the nonaffected areas. The greater the depth, the lower the $\mathrm{pH}$ value. In 2012, the depth results were 5.8\% lower; in 2017 they were $8.4 \%$ lower. The amount of carbonate content in 2012 and 2017 was close to zero.

All the samples collected in 2012 (Impact 12) had an increase in $\mathrm{pH}$ value ranging from 7 to $33 \%$ compared to Blank 12 samples prior to treatment. Half of the samples analyzed remained $\mathrm{pH}$ acidic, the other half
$\mathrm{pH}$ value increased to neutral. With the depth of sample collection, $\mathrm{pH}$ changes did not show a clear trend. Five from the 15 measured profiles show a higher $\mathrm{pH}$ value in the depth of $30 \mathrm{~cm}$, the remaining 10 profiles, on the other hand, show a higher $\mathrm{pH}$ value on the surface.

Five years after road construction, increased $\mathrm{pH}$ values were observed in all samples. In the first and third segments (X1, X3), the Impact 17 samples reach $\mathrm{pH}$ value of 8 . Compared to Blank 17 results, they are $42 \%$ higher compared to Impact 12 results, with an increase of $23 \%$. Unlike in 2012, most of the $\mathrm{pH}$ values have already reached neutral levels. Only samples from

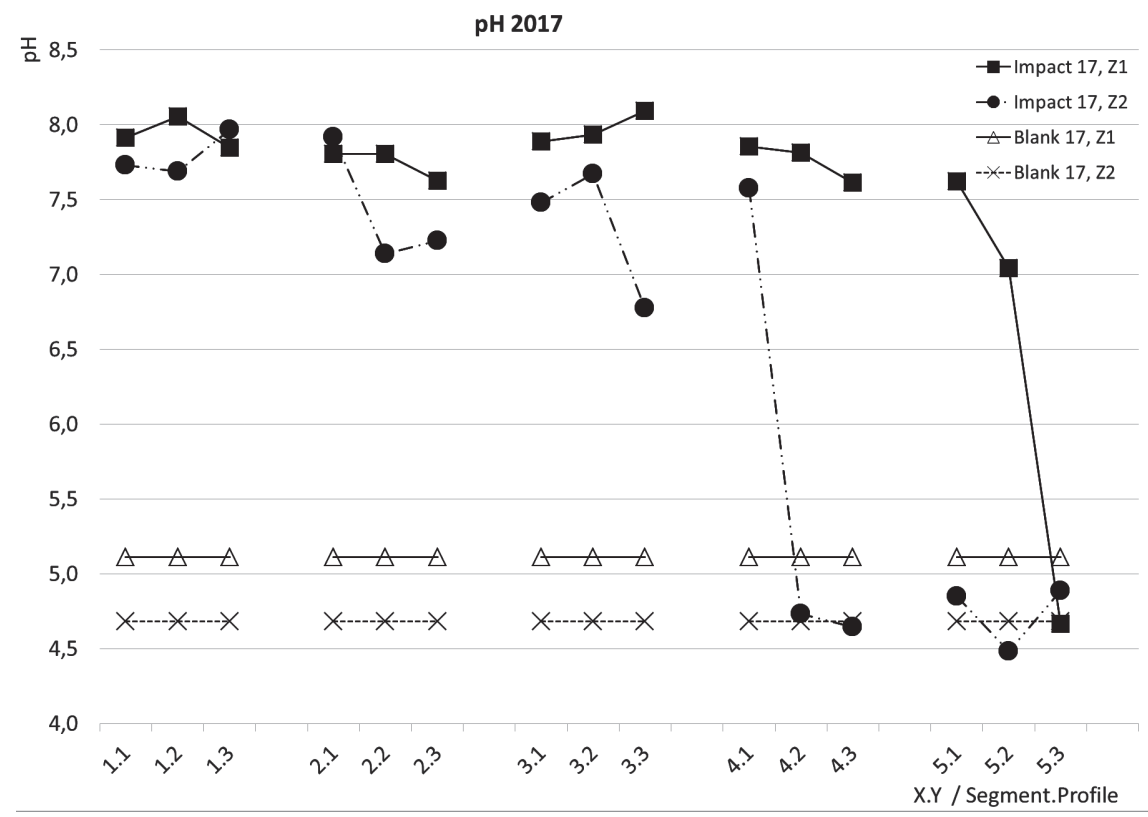

Fig. 5. Results of pH analysis from 2017. 


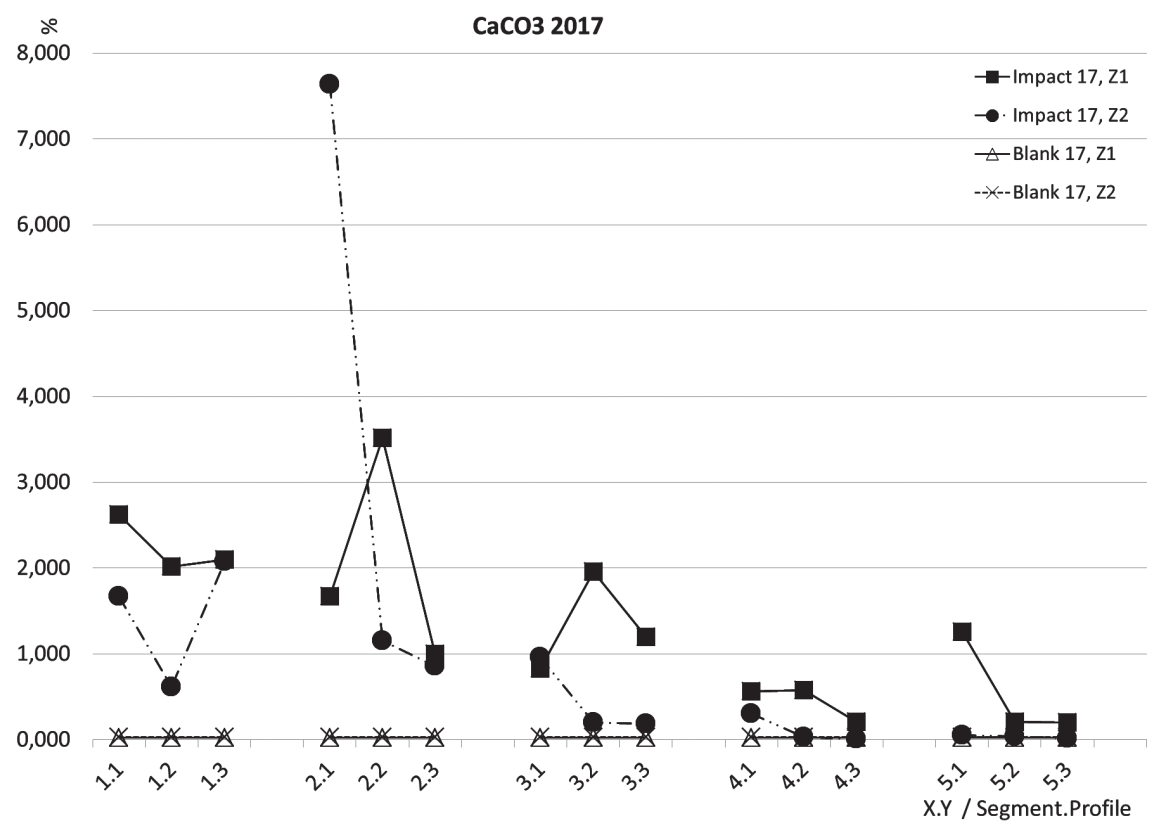

Fig. 6. Results of $\mathrm{CaCO}_{3}$ analysis from 2017.

the last two segments (X4, X5) remained with acidic $\mathrm{pH}$ value. However, the values taken at surface $\mathrm{Z1}$ and at depth Z2 already show a similar trend compared to 2012 , and of the 15 measured profiles, an increase occurs in only 3 profiles, and in the other 12 profiles $\mathrm{pH}$ shows lower values with depth. With respect to distance $\mathrm{Y}$ from the roadside, the samples show a non-uniform trend in terms of decrease or increase, as well as the 2012 samples. In 3 profiles in 3 different segments, the $\mathrm{pH}$ at distance $\mathrm{Y} 1, \mathrm{Y} 2$ and $\mathrm{Y} 3$ is almost constant, in the other 2 cases it dropped rapidly between $\mathrm{Y} 1$ and $\mathrm{Y} 3$ by up to $39 \%$. In the longitudinal direction of the road in the direction of gradient from the segment X1 to X5 $\mathrm{pH}$ values show a gradual decrease in the upper layer by $12 \%$ and in the lower part by up to $37 \%$ (Fig. 5). Although the change in the percentage of carbonate in the year 2017 is up to $99 \%$, the absolute value, which does not exceed $8 \%\left(\mathrm{CO}_{3}\right)^{2-}$, is medium high, so not very significant (Fig. 6).

\section{Statistical Analysis Results}

Probability $\mathrm{p}_{\mathrm{f}}$ was determined assuming Gaussian (normal) probability distribution for all 60 samples taken at individual depths $\mathrm{Z} 1$ and $\mathrm{Z} 2$, profiles $\mathrm{Y} 1-\mathrm{Y} 3$ in each segment X1-X5 as well as in the years 2012 and 2017. The results of statistical analysis for all samples show that probability $p_{f}$ is very low, close to zero. As result, the assumption that material leaching influences the ecosystem only in the close vicinity of the road should be confirmed. Illustrative results for segment X1 in 2017 are presented in Table 2.

\section{Influence of Pavement Construction on the Surrounding Environment}

The influence of human activities as a result of the construction and use of structures including the forest roads on the surrounding environment is very complex and has been documented by many studies

Table 2. Results of statistical analysis, segment X1, 2017.

\begin{tabular}{|c|c|c|c|c|c|}
\hline \multirow{3}{*}{ Segment } & \multirow{3}{*}{ Profile } & \multicolumn{4}{|c|}{2012} \\
\hline & & \multicolumn{3}{|c|}{$\mathrm{pH}$} & \multirow[b]{2}{*}{$\mathrm{p}_{\mathrm{f}}$} \\
\hline & & Mean & St. Deviation & Blank & \\
\hline \multirow{3}{*}{$\mathrm{Z1}$} & Y1 & 7.912 & 0.011662 & \multirow{3}{*}{5.114} & $0.000000 \mathrm{E}+00$ \\
\hline & Y2 & 8.056 & 0.022450 & & $0.000000 \mathrm{E}+00$ \\
\hline & Y3 & 7.848 & 0.016000 & & $0.000000 \mathrm{E}+00$ \\
\hline \multirow{3}{*}{$\mathrm{Z} 2$} & Y1 & 7.729 & 0.022400 & \multirow{3}{*}{4.683} & $0.000000 \mathrm{E}+00$ \\
\hline & Y2 & 7.690 & 0.030332 & & $0.000000 \mathrm{E}+00$ \\
\hline & Y3 & 7.970 & 0.014142 & & $0.000000 \mathrm{E}+00$ \\
\hline
\end{tabular}


$[22,23]$. Roads reduce the forested surface and damage the nearby vegetation because they cause changes in its growth [24]. In [25], the influence of mechanical processes associated with pavement construction on erosion and on damage of the surrounding vegetation is studied. But the above publications document only the impacts of the structural activities necessary to prepare the site for pavement construction, i.e., the influence of deforestation, which increases the possibility of erosion or the consequences of the structural layers compaction, leading to a reduction of soil porosity and thus to a reduction of plant rooting.

However, no studies have been found to analyze the influence of the road subgrade improving materials on total carbonates and on the $\mathrm{pH}$ changes and thus their influence on the road surrounding biodiversity. Some studies [26-28], however, deal with the influence of other human activities on the change of chemistry in surrounding ecosystems. The study [26] deals with the influence of cement dust from a cement plant on the environment. Soil samples were collected at different distances $(\max 25 \mathrm{~km})$ from a cement plant and an influence of cement dust on soil quality defined by $\mathrm{pH}$ changes was observed. Furthermore, it was observed that alkaline dust emitted from a cement plant is closely associated with the rise of soil $\mathrm{pH}$ due to greater accumulation of $\mathrm{CaCO}_{3}$. The study [27] deals with roadside areas affected by heavy metal pollution due to intensive motorized traffic. This research determined the heavy metal content of hollyhock (Alcea rosea L.) in roadside soils of the Van Lake Basin. The mean content of metals (for example $\mathrm{Mn}, \mathrm{CU}$ and $\mathrm{Zn}$ ) in leaves sampled from the roadside areas was significantly higher than mean heavy metal contents in leaves sampled from areas $30 \mathrm{~m}$ from the roadside. The next study [28] dealing with the negative impact of human activities on the surrounding ecosystems follows contamination of agricultural land by heavy metals $\mathrm{Pb}$ and $\mathrm{Zn}$ from a retention reservoir in southeastern China. Soil microorganisms and enzyme activities involving soil organic carbon and nitrogen decomposition and stabilization were decreased due to the toxic $\mathrm{Pb}-\mathrm{Zn}$ tailings. Therefore, soil organic carbon and total nitrogen accumulate, and an "elusive" carbon and nitrogen pool forms in the paddy fields compared with cornfields in the $\mathrm{Pb}-\mathrm{Zn}$ tailings-contaminated karst area.

The mentioned examples support the results of the presented study on the influence of materials for LVR pavement improvement on the changes in chemistry in close vicinity and the ability of the surrounding soils under the influence of these contaminants to change the original quality. Determined $\mathrm{pH}$ and $\mathrm{CaCO}_{3}$ changes correlate with the changes induced by different and mainly bigger contamination sources.

On the other hand, the indirect effects of $\mathrm{pH}$ changes on vegetation quality are documented. For example, acidic soil with a $\mathrm{pH}$ below 4, with enough soluble $\mathrm{Al}^{3+}$ [29], can cause damage to most plants, although solutions alone do not pose a problem at this level of $\mathrm{pH}$. In conditions of extreme acidity, this occurs together with $\mathrm{Mg}$ or SI. In general, the effect of $\mathrm{pH}$ on plant growth occurs at the nutritional level [30]. For optimum plant nutrient supply and for maximum availability, the neutral $\mathrm{pH}$ is in the interval 6.0-7.5.

The use of materials containing lime to improve the pavement subgrade has many implications for soil and plant growth in the surroundings. The influence of carbonates on vegetation as well as on different soil characteristics varies from positive to negative. From the experimental test, the influence of carbonates on the increase of $\mathrm{OH}^{-}$ions and reduction of $\mathrm{H}^{+}$in the soil solution [31], as well as on the reduction of plant production can be observed. As a result, there is better particle and structure aggregation, improved soil aeration and water movement, and reduction of $\mathrm{Al}, \mathrm{Mn}$ and Fe toxicity; the regulation of $\mathrm{P}$ and $\mathrm{MO}$ availability and the development conditions of microorganisms may also improve. The most important negative consequences are the destruction of the porous granular structure, the increase in the rate of decomposition of organic matter, and the immobilization or reduction of availability of nutrients such as $\mathrm{Mn}, \mathrm{Zn}$, and B [32]. Also, $\mathrm{CaCO}_{3}$ suppresses $\mathrm{Mg}$ obstruction and also affects the $\mathrm{Ca} / \mathrm{K}$ ratio and can induce shortcomings of $\mathrm{K}$.

\section{Conclusions}

In order to determine the impact of building materials of LVR pavement construction on surrounding ecosystems, changes in chemistry were quantified in the vicinity of the Kuběnka forest road, which was built as an experimental construction for testing both standard as well as innovative materials that are able to improve the load-bearing capacity of the subsoil. To analyze the impact of five types of improving materials, chemical tests were carried out to determine $\mathrm{pH}$ and total carbonate values in time.

The presented study is a unique presentation showing levels of chemistry before the beginning of building operations, changes in soil chemistry after the completion in 2012 and after five years of road use in five segments, three profiles and two depth levels. In the monitored area the subsoil is identical to the geotechnical classification in all segments (X2-X5); it is F4-CS. Only in the first segment, X1, is S4-SM, and with the distance from the pavement it changes to F6-CL. The soil is acidic with $\mathrm{pH}$ value from 4 to 5 on the scale and carbonate values are close to zero in 2012. This seems typical for this region. Five years after road construction in 2017, an increase in both monitored parameters can be observed. The $\mathrm{pH}$ value changed from acidic to neutral or slightly alkaline due to the carbonate effect. The amount of carbonate is mediumhigh according to the presented scale.

The first four segments that were improved using hydraulic binders (fluid fly ash, lime and Dorosol) 
showed $\mathrm{pH}$ increase with a maximum of 8.1 for segment $\mathrm{X} 3$. The increase of carbonates in these segments is on average $2.5 \%$, the maximum for segment $\mathrm{X} 2$ being $8 \%$. The smallest changes from the original state can be seen in segment $\mathrm{X} 5$, where $\mathrm{pH}$ significantly increased only in the top layer Z1 of the first profile Y1.

Presented results document the movement of improving materials from the subgrade by wind and water to the road shoulder, towards drainage systems and to the surrounding environment [23]. A comparison of the changes in the individual profiles Y1-Y3 and depths $\mathrm{Z} 1$ and $\mathrm{Z} 2$ do not show any clear trend in the material leaching. In all segments X1-X5 and in almost all profiles $\mathrm{Y} 1-\mathrm{Y} 3$ (except $\mathrm{X} 1 / \mathrm{Y} 1$ ), the maximum increases of $\mathrm{pH}$ values are observed on the surface.

Concerning $\mathrm{pH}$ changes in time, the maximum increase in $\mathrm{pH}$ values in 2012 was observed in the Y2 profiles, i.e., $2 \mathrm{~m}$ from the road edge, in all segments except X3. In 2017, the maximum values were observed in the Y1 profiles, i.e., closest to the construction, for all segments except X1. Comparing the changes in 2012 and 2017, it can be stated that all segments and all measured profiles except for X5/Y3 show a significant increase in $\mathrm{pH}$ value for samples taken on the surface.

The carbonate value showed no significant changes in 2012 and it was close to zero. In 2017 there was a slight increase in all segments to low level. The only exception is $\mathrm{X} 2 / \mathrm{Y} 2$, in which the carbonate value increased to medium level.

The performed statistical analysis confirmed the assumption that in all road segments the surrounding ecosystem is affected by material leaching only in the close vicinity of the road, and distant areas are not affected.

A good way to minimize the above-mentioned movement seems to use the vegetative control using a vegetation system located near the forest road, i.e., phytoremediation. Moreover, the ground part of the plants will be a barrier to dust generated during vehicle movement. To reduce erosive activity it is therefore recommended to maintain the protective vegetation strips along the drainage and slope areas and to minimize the runoff of excess water on the soil surface.

\section{Acknowledgements}

Our work was supported by the Specific University Research Fund of the FFWT Mendel University in Brno, Project No. LDF-TP-2019002, and by the project FAST-S-18-5264, Department of Landscaping and Landscape Conservation, University of Technology Brno.

\section{Conflict of Interest}

The authors declare no conflict of interest.

\section{References}

1. CHEN H.L., KOPROWSKI J.L. Differential Effects of Roads and Traffic on Space Use and Movements of Native Forest - Dependent and Introduced Edge - Tolerant Species. doi: 10.1371/journal.pone.0148121, 2016.

2. Definition of Erosion. https://definicion.de/erosion/ 2019 [In Spanish].

3. HACISALIHOGLU S., GÜMÜŞ S., KEZIK U., KARADAK H. Impact of Forest Road Construction on Topsoil Erosion and Hydro-Physical Soil Properties in a Semi-Arid Mountainous Ecosystem in Turkey. Polish Journal of Environmental Studies, 28 (1), 113, 2019.

4. VAN DIJCK S.J.E., VAN ASCH, W.J. Compaction on loamy soils due to tractor traffic in vineyards and orchards and its effect on infiltration in southern France. Soil \& Tillage Research, 63, 141, 2002.

5. NEGRÍN Z., ARÉVALO J.R. Tree Species Composition and Structure near Road Borders in the Laurel Forest of Anaga (Tenerife - Islas Canarias). ISSN 1843-5386, 2016.

6. GARCÍA J.M.R. The effect of land uses on soil erosion in Spain: a review. Catena, 81, 1, 2010.

7. FLORIAN A., ŠEVELOVÁ L., ŽÁK J. Influence of environmental humidity on mechanical properties of natural and recycled unbound materials. Acta Universitatis agriculturae et silviculturae Mendelianae Brunensis, ISSN 1211-8516, 63 (2), 405, 2015.

8. MEGHARAJ M., RAMAKRISHNAN B. Bioremediation approaches for organic pollutants: A critical perspective. Environment international, 37 (8), 1362, 2011.

9. PERDIKOU S., NICHOLAIDES D. Weather effects on recycled concrete used as a paving material for roads. doi 10.1007/s11069-013-0561-x, 2013.

10. SÁENZ V.L. Evaluation of Erosion Processes in Unpaved Forest Roads in Mountain Areas (Northwest Iberian system). University of Zaragoza, Department of Geography and Regional Planning, ISBN 978-84-692-5515-5, 2009 [In Spanish].

11. QGIS Version 3.4 [software]. https://www.qgis.org/es/site/, 2019.

12. https://es.climate-data.org, 03/04/2019.

13. ŠEVELOVÁ L., HAUSER J., ZEDNÍK P., LAŽEK D., MATULA R., KOZUMPLIKOVÁ A., FLORIAN A. Methodical Guide to the Design and Implementation of Pavement of Low Volume Roads. Certified Methodology 23327/2015-MZE-16222/M108, ISBN 978-80-7509-261-8, 62, 2015 [In Czech].

14. HAUSER J., ŠEVELOVÁ L., MATULA R., ZEDNÍK P. Optimization of low volume road pavement design and construction. Journal of Forest Science, 64 (2), 74, 2018.

15. ČSN EN ISO 17892-1 (721007): Geotechnical investigation and testing - Laboratory testing of soil - Part 1: Determination of water content.Institute for Technology Standardization, Me-trology and State Testing. Praha, 2015 [In Czech].

16. UNMZ. ČSN EN ISO 17892-4 (721007): Geotechnical investiga-tion and testing - Laboratory test-ing of soil Part 4: Determination of particle size distribution. Institute for Technology Standardiza-tion, Metrology and State Testing. Praha, 2017 [In Czech].

17. UNMZ. ČSN EN ISO 17892-12 (721007): Geotechnical investiga-tion and testing - Laboratory test-ing of soil Part 12: Determina-tion of the liquid and plastic limits. 
Institute for Technology Stan-dardization, Metrology and State Testing. Praha, 2018 [In Czech].

18. UNMZ. ČSN EN ISO 14689-1: Geotechnical investigation and testing - Identification and classi-fication of rock - Part 1: Identifi-cation and description. Institute for Technology Standardization, Metrology and State Testing. Praha, 2004 [In Czech].

19. UNMZ. ČSN EN ISO 14688-2: Geotechnical investigation and testing - Identification and classi-fication of soil Part 2: Principles for a classification. Institute for Technology Standardization, Me-trology and State Testing. Praha, 2005 [In Czech].

20. ISO 10390:1994, https://www.iso.org/standard/18454.html. 15/01/2019.

21. ISO 10693:1995, https://www.iso.org/standard/18781.html. 15/01/2019.

22. DELGADO A.J.R., ARÁVELO J.R., FERNANDÉZPALACIOS J.M. Consequences of Road Fragmentation: Roadside Effects on Laurel and Tenerife Pine For-est. Insular Ecology, Spanish As-sociation of Terrestrial Ecology (AEET) Cibaldo insular de La Palma, 181, 2004 [In Spanish].

23. HU X., WU Z., WU CH., YE L., LAN CH., TANG K., XU L., QUI R. Effects of road network on diversiform forest cover changes in the highest coverage region in China: An analysis of sampling strategies. Science of the Total Environment 565, 28, 2016.

24. CABRERA M., AGREL F. Application of Bottom Ash From Olive Biomass in the Manufacture of Recycled Cement-Soil for Roads. Technical magazine cement concrete, ISSN: 0008-8919, 961, 2014 [In Spanish].

25. Handbook for Stabilizing Lime Treated Soil; Stabilization and Modification. National Lime As-sociation, 2006 [In Spanish].
26. BILEN S., BILEN M., TURAN V. Relationships between Cement Dust Emissions and Soil Properties. Polish Journal of Environmental Studies, 28 (5), 3089, 2019.

27. KAYA I., GÜLSER F. Determining Heavy Metal Contents of Hollyhock (Alcea rosea L.) in Roadside Soils of a Turkish Lake Basin. Polish Journal of Environmental Studies, 27 (5), 2081, 2018.

28. LI Q., HU Q., ZHANG CH., JIN Z. Effects of Pb, Cd, $\mathrm{Zn}$, and $\mathrm{Cu}$ on Soil Enzyme Activity and Soil Properties Related to Agricultural Land-Use Practices in Karst Area Contaminated by $\mathrm{Pb}-\mathrm{Zn}$ Tailings. Polish Journal of Environmental Studies, 27 (6), 2623, 2018.

29. GAZEY CH. Effects of soil acidity. https://www.agric. wa.gov.au/soil-acidity/effects-soil-acidity?nopaging=1, 2018.

30. MILLER J.O. Soil pH Affects Nutrient Availability. Technical Report University of Maryland Extension, Fact Sheet FS-1054, doi: 10.13140/RG.2.1.2423.5768, 2016.

31. GOULDING K.W.T. Soil acidification and the importance of liming agricultural soils with particular reference to the United Kingdom. Soil Use Manag, doi: 10.1111/sum.12270, 32 (3), 390, 2016.

32. BRAVO S., AMORÓS J.A., PERÉZ DE LOS REYES C., GARCÍA F.J., MORENO M.M., SÁNCHEZ-ORMENO M., HIGUERAS P. Influence of the soil $\mathrm{pH}$ in the uptake and bioaccumulation of heavy metals ( $\mathrm{Fe}, \mathrm{Zn}, \mathrm{Cu}, \mathrm{Pb}$ and $\mathrm{Mn}$ ) and other elements $(\mathrm{Ca}, \mathrm{K}, \mathrm{Al}, \mathrm{Sr}$ and $\mathrm{Ba})$ in vine leaves, Castilla-La Mancha (Spain). Journal of Geochemical Exploration, 174, 79, 2017. 